\title{
Development of a Multiplex Reverse Transcription-Polymerase Chain Reaction Assay for the Simultaneous Detection of Three Viruses in Leguminous Plants
}

\author{
*Co-corresponding authors \\ Y. Yoon \\ Tel: +82-55-350-1264 \\ Fax: +82-55-352-3059 \\ E-mail:yoonyn@korea.kr \\ S.-H. Lee \\ Tel: $+82-53-950-5763$ \\ Fax: +82-53-950-6758 \\ E-mail: suheon@knu.ac.kr
}

Received September 17, 2018 Revised November 1, 2018 Accepted November 2, 2018

\author{
Chung Youl Park ${ }^{1,2}$, Hyun-Geun Min ${ }^{1}$, Hong-Kyu Lee', Rameswor Maharjan³, \\ Youngnam Yoon $^{3 *}$, and Su-Heon Lee ${ }^{1,4 *}$ \\ ${ }^{1}$ School of Applied Biosciences, Kyungpook National University, Daegu 41566, Korea \\ ${ }^{2}$ Present Address: Seed Testing \& Research Center, Korea Seed \& Variety Service, Gimcheon 39660, Korea \\ ${ }^{3}$ Crop Production Technology Research Division, NICS, RDA, Miryang 50426, Korea \\ ${ }^{4}$ Institute of Plant Medicine, Kyungpook National University, Daegu 41566, Korea
}

\begin{abstract}
A multiplex reverse transcription-polymerase chain reaction (mRT-PCR) assay was developed for the detection of Clover yellow vein virus (CIYVV), Peanut mottle virus (PeMoV), and Tomato spotted wilt virus (TSWV), which were recently reported to infect soybean and azuki bean in Korea. Species-specific primer sets were designed for the detection of each virus, and their specificity and sensitivity were tested using mixed primer sets. From among the designed primer sets, two combinations were selected and further evaluated to estimate the detection limits of uniplex, duplex, and multiplex RT-PCR. The multiplex RT-PCR assay could be a useful tool for the field survey of plant viruses and the rapid detection of CIYVV, PeMoV, and TSWV in leguminous plants.
\end{abstract}

Keywords: Clover yellow vein virus, Multiplex RT-PCR, Peanut mottle virus, Primer combinations, Tomato spotted wilt virus
Soybean (Glycine max) and azuki bean (Vigna angularis) are considered the most economically important among leguminous crops and are cultivated worldwide. They occupy an important place in Korean diet and cuisine. Legumes have high nutritional value, as they are rich sources of calories, certain minerals, and vitamins (lqbal et al., 2006). In particular, fermented soybean foods are known to have many health benefits. To date, 12 viruses, Alfalfa mosaic virus (AMV), Bean common mosaic virus (BCMV), Clover yellow vein virus (CIYV), Cowpea mosaic virus (CPMV), Cucumber mosaic virus (CMV), Soybean dwarf virus (SbDV), Soybean mosaic virus (SMV), Soybean yellow common mosaic virus (SYCMV), Soybean

Research in Plant Disease

pISSN 1598-2262, elSSN 2233-9191

www.online-rpd.org yellow mottle virus (SYMMV), Peanut mottle virus (PeMoV), Peanut stunt virus (PSV), and Tomato spotted wilt virus (TSWV), have been reported to infect in soybean and azuki bean in Korea (Kim, 2006; Lee et al., 2013, 2015; Nam et al., 2009, 2012). Among these 12 viruses, three viruses, CIYW, PeMoV and TSWV, were recently reported to infect soybean, and two viruses, PeMoV and TSWV, were reported to infect red bean (Lim et al., 2014; Shin et al., 2014; Yoon et al., 2018).

Previous studies have reported that the infection rate of SMV was the highest among these viruses. In Korea, BCMV had a consistently high rate of infection in red bean (Yoon, 2017). However, recently, there has been an increase in the infection rates of SYMMV and SYCMV in soybean (Cho et al., 2013; Seo et al., 2014). Factors such as the dissemination of new seed varieties and changes in climate cause unpre- 
dictability in the distribution and severity of viral infections. Therefore, new, more rapid detection methods are needed.

In 2011, two combinations of primer sets, combination 1: AMV, SYCMV, and SYMMV and combination 2: SMV, SbDV, and PSV, were developed by the Rural Development Administration (RDA), Korea, for the simultaneous detection of six soybean-infecting viruses (Patent Code No. 1012503880000, http://www.kipo.go.kr). However, an RNA-based multiplex polymerase chain reaction ( $\mathrm{MPCR}$ ) has not yet been developed for the simultaneous detection of CIYW, PeMoV, and TSWV. mPCR allows for rapid and low-cost detection owing to its ability to simultaneously detect multiple target pathogens in a single reaction (Asano et al., 2015; Yao et al., 2014). Therefore, this study was undertaken to develop an mPCR assay for the simultaneous detection of CIYW, PeMoV, and TSWV from leguminous plants.

Sample collection and processing. A CIYW-infected soybean sample was used as a positive control, and this sample was registered in GenBank (KF975894). A PeMoV-infected soybean leaf sample (KJ664838) and a PeMoV-infected azuki bean leaf sample (LC201922) were used as PeMoV positive controls. TSWV-positive leaf samples of soybean (MF417648) and azuki bean (not registered) were provided by the $\mathrm{Na}$ tional Institute of Crop Science, RDA, Korea. All virus-infected samples were collected from a field in Korea.

Total RNA was extracted from all samples using an Easy Spin $^{\text {TM }}$ (DNA-free) Total RNA Extraction kit (Intron, Daejeon, Korea) by following the manufacturer's protocol. The concentration of the total RNA extracted was measured using a NanoDrop ND-1000 spectrophotometer (NanoDrop, Wilmington, DE) and estimated to range from $88.84 \mathrm{ng} / \mu \mathrm{l}$ to $407.12 \mathrm{ng} / \mu \mathrm{l}$. First-strand cDNA was synthesized using SuperiorScript III Reverse Transcriptase (Enzynomics, Daejeon, Korea) and random N25 primers according to the manufacturer's instructions. Reverse transcription-PCR (RTPCR) was then carried out using cDNA as a template.

Primer design. Primers specific to CIYVV, PeMoV, and TSWV were designed based on the complete genome sequences available on GenBank. The genomic sequences of three CIYW isolates (NC002600, KF977830, and AF023848), two PeMoV isolates (NC003536 and AB011819), and three TSWV isolates (JF960235, KT717693, and KP008134) were first downloaded from GenBank. These sequences were then aligned with those of 134 other Potyvirus species, following which primers were designed from the conserved regions. Sequences of TSWV isolates were also aligned with those of 11 Orthotospovirus genera, following which the primers were designed from the conserved regions. In total, five

Table 1. Oligonucleotide sequences for the two different primer combinations used for the detection of the three viruses

\begin{tabular}{|c|c|c|c|c|}
\hline Combination no. & Virus name & Primer name & Sequences ${ }^{*}\left(5^{\prime}\right.$ to $\left.3^{\prime}\right)$ & Amplicon size (bp) \\
\hline \multirow{6}{*}{1} & \multirow[t]{2}{*}{ CIYVV } & CIYVV-F32 & GCGCGGAATGAGGATATTGA & \multirow[t]{2}{*}{447} \\
\hline & & CIYVV-R29 & ATTGGCTGACTGCACTCTTG & \\
\hline & \multirow[t]{2}{*}{ PeMoV } & PeMoV-F20 & GAGTCAGTTGAGAGGTTACC & \multirow[t]{2}{*}{599} \\
\hline & & PeMoV-R15 & CGCATTCGTCTTGCATGCG & \\
\hline & \multirow[t]{2}{*}{ TSWV } & TSWV-S-F130 & TTCAGTCTGGGGATCAACTG & \multirow[t]{2}{*}{947} \\
\hline & & TSWV-S-R1076 & GAACAATGTTGTAAGGCTCC & \\
\hline \multirow{6}{*}{2} & \multirow[t]{2}{*}{ CIYVV } & CIYVV-F32 & GCGCGGAATGAGGATATTGA & \multirow[t]{2}{*}{447} \\
\hline & & CIYVV-R29 & ATTGGCTGACTGCACTCTTG & \\
\hline & \multirow[t]{2}{*}{ PeMoV } & PeMoV-F30 & GCTTCATTGCTTGGGTATGG & \multirow[t]{2}{*}{560} \\
\hline & & PeMoV-R26 & TCTGCTATGCTCTGCGCAC & \\
\hline & \multirow[t]{2}{*}{ TSWV } & TSWV-S-F2135 & СTTCCTTAGCATTAGGATTGC & \multirow[t]{2}{*}{682} \\
\hline & & TSWV-S-R2816 & CTAAGGTTAAGCTCACTAAGG & \\
\hline
\end{tabular}

\footnotetext{
"All primers for each virus were designed within the conserved regions: nuclear inclusion $\mathrm{A}$ (Nla) protease for $\mathrm{CIYVV}$; cylindrical inclusion (CI),
} 6K2, Nla-Viral protein genome (VPg) protein for PeMoV; nucleocapsied (NC) protein for TSWV. 
species-specific primer sets of CIYVV and PeMoV and eight species-specific primer sets of TSWV were designed.

Evaluation of primer sets. First, the specificity of the designed primer sets was tested by uniplex RT-PCR. One

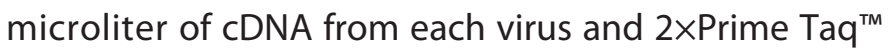
Premix (Genet Bio, Daejeon, Korea) were used to carry out each uniplex PCR. PCR cycling conditions were as follows: initial denaturation at $95^{\circ} \mathrm{C}$ for $10 \mathrm{~min}, 35$ cycles of denaturation at $95^{\circ} \mathrm{C}$ for $30 \mathrm{~s}$, annealing at $55^{\circ} \mathrm{C}$ for $30 \mathrm{~s}$, and extension at $72^{\circ} \mathrm{C}$ for $1 \mathrm{~min}$, followed by a final extension at $72^{\circ} \mathrm{C}$ for $5 \mathrm{~min}$. The sizes of the PCR products were finally analyzed using agarose gel electrophoresis ( $2 \%$ agarose). The newly designed species-specific primers successfully amplified their targets in the uniplex RT-PCR. The RT-PCR amplicons were purified using the Expin Combo GP mini prep kit (GeneALL, Seoul, Korea), and each viral sequence was confirmed by bi-directional sequencing. For the selection of primer set combinations for multiplex RT-PCR, various primer sets were tested on the basis of target size. Duplex and multiplex RTPCR for the detection of CIYW, PeMoV, and TSWV were then carried out using the PCR components and cycling conditions mentioned previously. The cDNA of each virus was mixed and made up one, and then used as a positive control. Test results showed that the two combinations of primer sets successfully amplified the target sizes, and no non-specific bands were observed when the resulting amplicons were analyzed by agarose gel electrophoresis (Table 1, Fig. 1).

Second, the sensitivity of the two combinations of primer sets was tested using 10-fold serial dilutions of the cDNA and subjecting these to uniplex, duplex, and multiplex RT-PCR. The results of the sensitivity test using the first combination were as follows: i) uniplex RT-PCR: CIYVV, PeMoV, and TSWV were detectable up to $10^{-2}, 10^{-2}$, and $10^{-4}$ dilutions (Fig. 2A); ii) duplex RT-PCR: PeMoV+CIYV, CIYV +TSWV, and PeMoV+TSWV were detectable up to $10^{-2}$, $10^{-4}$, and $10^{-3}$ dilutions (Fig. 2B); and iii) multiplex RT-PCR: $\mathrm{CIYW}+\mathrm{PeMoV}+\mathrm{TSW}$ was detectable up to $10^{-3}$ dilution (Fig. $2 \mathrm{C})$. The sensitivity of the second primer set combination was at least 10-fold higher than that of the first primer set combination in the uniplex and duplex RT-PCR, whereas it was 100 -fold lower than that of the first primer set combination in multiplex RT-PCR (data not shown). Therefore, the first primer set combination was selected for the detection of the three viruses using multiplex RT-PCR in this study.

The multiplex RT-PCR assay developed and validated in this study can, therefore, be used as a rapid and sensitive method for detecting CIYV, PeMoV, and TSWV in soybean and azuki bean plants. In Korea, soybean is one of the most important cultivated crops, which is why viral diseases in soybeans are being continuously investigated. The multiplex RTPCR developed based on the information generated by this study could contribute to rapid detection of plant viruses in field surveys.

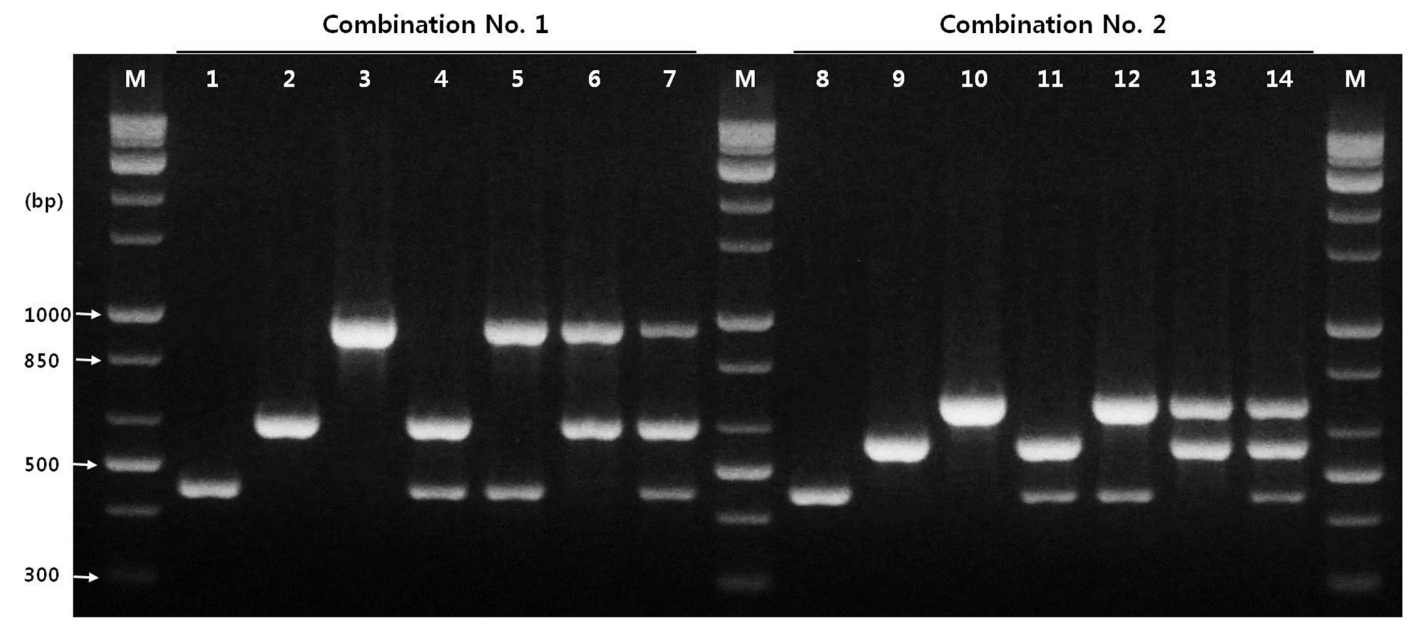

Fig. 1. Simultaneous detection using the finally selected primer combinations for the three viruses (Clover yellow vein virus, CIYV; Peanut mottle virus, PeMoV, and Tomato spotted wilt virus, TSWV) by multiplex PCR. Lane M: 1 kb DNA ladder (BioFACT, Daejeon, Korea), Lane 1 and 8: 447 bp for CIYYV; Lane 2 and 9: 599 and 560 bp for PeMoV; Lane 3 and 10: 947 and 682 bp for TSWV; Lane 4 and 11: CIYVV+PeMoV; Lane 5 and 12: CIYV+TSWV; Lane 6 and 13: PeMoV+TSWV; Lane 7 and 14: CIYVV+PeMoV+TSWV. 

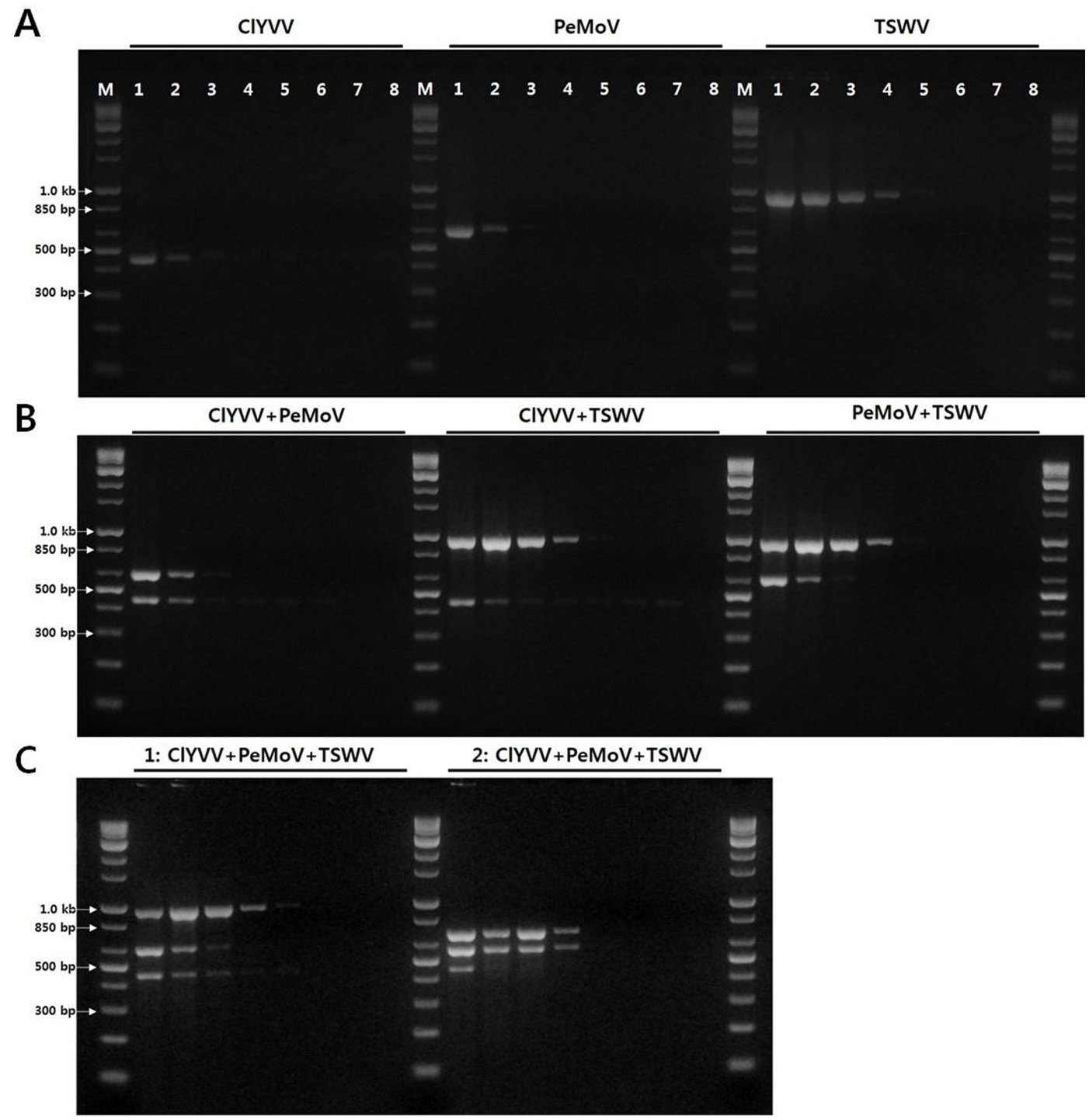

Fig. 2. Sensitivity test of uniplex-, duplex- and multiplex-PCR for the three legume viruses. (A) uniplex-PCR test results of CIYYV, PeMoV, and TSWV using the first primer combination, (B) duplex-PCR test results of CIYVV+PeMoV, CIYVV+TSWV, and PeMoV+TSWV using the first combination, (C) multiplex-PCR test results of CIYVV+PeMoV+TSWV and comparison of the two different primer combination sets no. 1 (left) and 2 (right). Lane M: $1 \mathrm{~kb}$ DNA ladder (BioFACT, Daejeon, Korea), Lane 1 to $8: 10^{-1}$ to $10^{-8}$ diluted CDNA.

\section{Conflicts of Interest}

No potential conflict of interest relevant to this article was reported.

\section{Acknowledgement}

This research was carried out with the support of the Cooperative Research Program for Agriculture Science and Technology Development (project no. PJ01112801), Rural
Development Administration, Republic of Korea.

\section{References}

Asano, S., Matsushita, Y., Hirayama, Y. and Naka, T. 2015. Simultaneous detection of Tomato spotted wilt virus, Dahlia mosaic virus and Chrysanthemum stunt viroid by multiplex RT-PCR in dahlias and their distribution in Japanese dahlias. Lett. Appl. Microbiol. 61: 113-120.

Cho, S. H., Kim, J. K., Li, M., Seo, E. Y., Lim, S. M., Hong, S. M. et al. 2013. Occurrence of three major soybean viruses, Soybean 
mosaic virus, Soybean yellow mottle mosaic virus and Soybean yellow common mosaic virus Revealed by a Nationwide Survey of Subsistence Farming Soybean Fields. Res. Plant Dis. 19: 319325. (In Korean)

Iqbal, A., Khalil, I. A., Ateeq, N. and Khan, M. S. 2006. Nutritional quality of important food legumes. Food Chem. 97: 331-335.

Kim, S. M. 2006. Identification of legume-infecting viruses in Korea and characterization of Soybean yellow mottle mosaic virus. Ph.D. thesis. Kyungpook National University, Daegu, Korea.

Lee, Y. H., Lim, S. T., Yoon, Y. N., Jeon, M. G., Yun, H. T., Ko, J. M. et al. 2013. Incidence of soybean viral diseases in Korea. Korea Soybean Digest. 29: 7-15. (In Korean)

Lee, Y. H., Yoon, Y. N., Yun, H. T., Baek, I. Y., Lim, S., Moon, J. S. et al. 2015. First report of Bean common mosaic virus infecting soybean in South Korea. Plant Dis. 99: 1189.

Lim, S., Lee, Y.-H., Igori, D., Zhao, F., Yoo, R. H., Lee, S.-H. et al. 2014. First Report of Peanut mottle virus Infecting Soybean in South Korea. Plant Dis. 98: 1285.

Nam, M., Kim, S. M., Domier, L. L., Koh, S., Moon, J. K., Choi, H. S. et al. 2009. Nucleotide sequence and genomic organization of a newly identified member of the genus Carmovirus, Soybean yellow mottle mosaic virus, from soybean. Arch. Virol. 154: 16791684.

Nam, M., Park, S. J., Kim, Y. J., Kim, J. S., Park, C. Y., Lee, J. S. et al. 2012. First report of Peanut stunt virus on Glycine max in Korea. Plant Pathol. J. 28: 330.

Seo, J. K., Park, J. Y., Kwak, H. R., Kim, M. K., Nam, M., Lee, S. H. et al. 2014. Severe outbreak of the emerging soybean viruses in Korea: an increasing threat. Plant Health Prog. 15: 122-123.

Shin, J.-C., Kim, M.-K., Kwak, H.-R., Choi, H.-S., Kim, J.-S., Park, C.-Y. et al. 2014. First Report of Clover yellow vein virus on Glycine max in Korea. Plant Dis. 98: 1283.

Yao, B., Wang, G., Ma, X., Liu, W., Tang, H., Zhu, H. et al. 2014. Simultaneous detection and differentiation of three viruses in pear plants by a multiplex RT-PCR. J. Virol. Methods 196: 113-119.

Yoon, Y. N. 2017. The characteristic of spatial-temporal virome and the survey and molecular detection of viruses infecting adzuki bean based on meta-transcriptome analysis. Ph.D. Thesis. Kyungpook National University, Daegu, Korea.

Yoon, Y. N., Jo, Y., Cho, W. K., Choi, H., Jang, Y., Lee, Y. H. et al. 2018. First report of Tomato spotted wilt virus infecting soybean in Korea. Plant Dis. 102: 461. 